\title{
FISCAL RESPONSIBILITY LEGISLATION AND FISCAL ADJUSTMENT: THE CASE OF BRAZILIAN LOCAL GOVERNMENTS
}

\author{
Luiz de Mello ${ }^{1}$ \\ Economics Department, OECD
}

\begin{abstract}
This paper discusses trends in fiscal adjustment in Brazil since the 1990s, with particular emphasis on the strengthening of institutions for fiscal policymaking, and its effect on local government finances and their ability to invest in infrastructure building and upgrading. Although fiscal adjustment, which is ongoing, has taken a toll on the government's ability to finance much-needed infrastructure investment, it is not the only culprit. A lack of budget flexibility, against a backdrop of increasing downward rigidities in current spending, also constrains the government's ability to invest. The paper argues that regulatory uncertainty in many sectors, particularly water/sanitation, in which the municipalities play a leading role, has discouraged private sector investment and that the financing of infrastructure building and upgrading goes beyond the municipal level of government. Higher-level jurisdictions are responsible for financing investment in energy and transport infrastructure, for example.
\end{abstract}

World Bank Policy Research Working Paper 3812, January 2006

The Policy Research Working Paper Series disseminates the findings of work in progress to encourage the exchange of ideas about development issues. An objective of the series is to get the findings out quickly, even if the presentations are less than fully polished. The papers carry the names of the authors and should be cited accordingly. The findings, interpretations, and conclusions expressed in this paper are entirely those of the authors. They do not necessarily represent the view of the World Bank, its Executive Directors, or the countries they represent. Policy Research Working Papers are available online at http://econ.worldbank.org.

1. This paper was prepared for presentation at the World Bank's Practioners' Conference on “Mobilizing Urban Infrastructure Finance in a Responsible Fiscal Framework”, Jaipur, India, 6-8 January, 2005. The author is indebted to José Roberto Afonso, Andrew Dean, Silvana Malle, Nanno Mulder and the seminar participants, in particular Sol Garson, for useful comments and discussions; and to Anne Legendre, for statistical assistance. Mailing address: OECD Economics Department, 2, rue André Pascal, 75775 Paris Cedex 16, France. Tel: (33-1) 4524-8752, Fax: (33-1) 4430-6384, E-mail: luiz.demello@oecd.org. 


\section{Introduction}

1. Brazil's fiscal adjustment since the floating of the Real in 1999 has been impressive, even under adverse conditions. This has been of paramount importance in the consolidation of macroeconomic stability in the period and to ensure that the dynamics of public indebtedness is sustainable. But fiscal adjustment has taken place on the back of revenue hikes and, to a lesser extent, a compression of public investment, rather than the retrenchment of current outlays. As a result, Brazil's tax-to-GDP ratio is now much higher than that of countries with comparable income levels, being close to the OECD average and nearly twice as high as that of the rest of Latin America. This suggests a quality problem: based on international experience, the composition of fiscal adjustment affects its likelihood of success in the sense of delivering a sustained reduction in indebtedness over time.

2. Against this background, this paper discusses trends in fiscal adjustment in Brazil since the 1990s, with particular emphasis on the strengthening of institutions for fiscal policymaking, as well as its effect on local governments and their ability to invest in infrastructure building and upgrading. The main issues to be highlighted are as follows:

- The strengthening of fiscal institutions has played an important role in instilling fiscal probity at all levels of government. Emblematic of developments in this area is the enactment of the Fiscal Responsibility Law in 2000. Market scrutiny also helps, and policymakers now appear to be responding more forcefully to changes in public indebtedness by delivering the primary budget surpluses needed to service their outstanding debt obligations.

- Fiscal adjustment is on-going and has taken a toll on the government's ability to finance muchneeded infrastructure investment. But fiscal retrenchment is not the only culprit for a lack of investment. Regulatory uncertainty in many sectors, particularly water/sanitation, in which the municipalities play a leading role, has also discouraged private sector investment. It also needs to be recognized that the financing of infrastructure building and upgrading goes beyond the municipal level of government. Higher-level jurisdictions are responsible for financing investment in energy and transport infrastructure, for example.

3. The paper is organized as follows. Section 2 reviews broad trends in fiscal adjustment since the early 1990s, focusing on debt sustainability. Section 3 discusses the main provisions of Fiscal Responsibility legislation. Section 4 discusses trends in municipal finances, including investment. Section 5 concludes.

\section{Trends in fiscal adjustment: the focus on debt sustainability}

4. Brazil's fiscal performance has improved over the years at all levels of government, owing predominantly to the need to contain the rise in public indebtedness (Table 1). ${ }^{2}$ Currently at about 52 percent of GDP, the consolidated net public debt is not only high but its composition, with relatively short maturities and a high share of securities paying floating interest rates, makes the debt dynamics overly sensitive to changes in market conditions. Exposure to foreign exchange risk has now been reduced considerably through the gradual retirement of foreign exchange-indexed debt since 2003. Continued effort is therefore needed towards fiscal consolidation in countries, such as Brazil, where public indebtedness is

2. See de Mello (2006) and OECD (2005), for more information. 
perceived as a source of vulnerability. Recent empirical evidence suggests that debt levels above 30-50 percent of GDP may not be sustainable in emerging markets. ${ }^{3}$

5. Against this background, a few considerations are noteworthy:

- Fiscal stance has responded swiftly to changes in the macroeconomic environment. The consolidated primary surplus -- including the central and sub-national levels of government -- has been raised over time to keep the debt-to-GDP ratio on a sustainable path (Figure 1). ${ }^{4}$ This has been the case even in periods of economic slowdown, making fiscal stance less counter-cyclical than desirable. Concern about the sustainability of public indebtedness calls for corrective action even in periods of below-potential growth, making fiscal consolidation, rather than short-term demand management, the overriding objective of fiscal policymaking in indebted countries. ${ }^{5}$ In fact, the OECD experience shows that a pro-cyclical fiscal stance is not uncommon in industrial countries, particularly when retrenchment is implemented to restore fiscal sustainability against a backdrop of high, or rising, indebtedness. ${ }^{6}$

3. The argument is that a typical emerging market may not be able to repay and re-finance its debt obligations due to its lower revenue ratio, its more volatile tax bases and its higher, more volatile spending on debt service. Budget financing is also affected by supply-side constraints in emerging markets, given their imperfect access to international capital markets and shallow domestic financial markets. Many emerging markets also face more "debt intolerance" than more mature economies in the sense that credit rating are often worse in some countries for the same level of indebtedness, reflecting individual countries' record in external debt repayment and macroeconomic stability. Reinhart et al. (2003) show that external debt intolerance is a good predictor of domestic debt default.

4. See de Mello (2006), for the estimation of a fiscal reaction function for Brazil. However, policy reactivity tends to be stronger in more mature economies. Recent research suggests that primary balances tend to have lower sensitivity to indebtedness in emerging markets than in industrial countries, controlling for other determinants of fiscal stance. This sensitivity is also affected by the level of indebtedness: it is estimated to be lower in emerging markets as the debt-to-GDP ratio rises (and not statistically significant when debt exceeds 50 percent of GDP) than in industrial countries (IMF, 2003).

5. The example of Latin America is illustrative. According to ECLAC analysis, in 13 out of the 17 cases in which GDP growth was above trend, the change in the cyclically adjusted public-sector balance was negative, reflecting an expansionary fiscal policy. There are also episodes in which the budget balance adjusted for the cycle exhibited little variation despite significant changes in the output gap, such as in Chile (1992-98), Brazil (1990-94) and Mexico (1995-97). See Martner and Tromben (2004), for more information.

6. The OECD experience suggests that public indebtedness is a key determinant of whether fiscal stance is pro-cyclical during downturns. But it is important to note that fiscal consolidation in a downturn need not be destabilizing so long as it restores confidence by putting the debt dynamics on a sustainable path. For example, Giavazzi et al. (2000), as well as Alesina and Ardagna (1998), among others, show that fiscal contractions may be expansionary in indebted OECD countries and that the composition of adjustment, via tax increases and/or expenditure cuts, affects the expansionary potential of fiscal retrenchment. See also OECD (2003a), Chapter IV, for more information. 
Table 1. Public sector fiscal outcomes, 1995-2004

Budget balance in per cent of GDP (a positive ratio indicates a surplus)

\begin{tabular}{|c|c|c|c|c|c|c|c|c|c|c|}
\hline & 1995 & 1996 & 1997 & 1998 & 1999 & 2000 & 2001 & 2002 & 2003 & 20043 \\
\hline Overall balance & -7.3 & -5.8 & -6.1 & -7.5 & -5.8 & -3.6 & -3.6 & -4.6 & -5.2 & -4.1 \\
\hline Central government $1 /$ & -2.4 & -2.9 & -2.6 & -4.9 & -2.7 & -2.3 & -2.1 & -0.8 & -4.1 & -3.3 \\
\hline Regional governments & -3.6 & -2.1 & -3.0 & -2.0 & -3.2 & -2.1 & -2.0 & -3.9 & -1.8 & -1.5 \\
\hline States & $\ldots$ & $\ldots$ & $\ldots$ & -1.8 & -2.7 & -1.8 & -1.9 & -3.3 & -1.5 & -1.3 \\
\hline Municipalities & $\ldots$ & $\ldots$ & $\ldots$ & -0.2 & -0.5 & -0.3 & -0.1 & -0.6 & -0.3 & -0.2 \\
\hline Public enterprises & -1.3 & -0.8 & -0.5 & -0.5 & 0.1 & 0.7 & 0.6 & 0.0 & 0.7 & 0.7 \\
\hline Interest payment & 7.5 & 5.8 & 5.2 & 7.5 & 9.0 & 7.1 & 7.2 & 8.5 & 9.6 & 8.4 \\
\hline Central government 1 / & 2.9 & 2.9 & 2.4 & 5.5 & 5.0 & 4.1 & 3.9 & 3.1 & 6.7 & 5.8 \\
\hline Regional governments & 3.4 & 2.2 & 2.3 & 1.8 & 3.3 & 2.6 & 2.9 & 4.6 & 2.7 & 2.5 \\
\hline States & $\ldots$ & $\ldots$ & $\ldots$ & 1.4 & 2.8 & 2.2 & 2.5 & 3.9 & 2.3 & 2.1 \\
\hline Municipalities & $\ldots$ & $\ldots$ & $\ldots$ & 0.4 & 0.5 & 0.4 & 0.4 & 0.7 & 0.4 & 0.4 \\
\hline Public enterprises & 1.3 & 0.7 & 0.5 & 0.2 & 0.6 & 0.3 & 0.4 & 0.7 & 0.2 & 0.1 \\
\hline Primary balance 2/ & 0.3 & -0.1 & -1.0 & 0.0 & 3.2 & 3.5 & 3.6 & 3.9 & 4.4 & 4.3 \\
\hline Central government 1 / & 0.5 & 0.0 & -0.3 & 0.6 & 2.3 & 1.9 & 1.8 & 2.4 & 2.6 & 2.6 \\
\hline Regional governments & -0.2 & 0.1 & -0.7 & -0.2 & 0.3 & 0.5 & 0.9 & 0.8 & 0.9 & 0.9 \\
\hline States & $\ldots$ & $\ldots$ & $\ldots$ & -0.4 & 0.2 & 0.4 & 0.6 & 0.6 & 0.8 & 0.8 \\
\hline Municipalities & $\cdots$ & $\cdots$ & $\cdots$ & 0.2 & 0.1 & 0.1 & 0.3 & 0.2 & 0.1 & 0.1 \\
\hline Public enterprises & -0.1 & -0.1 & 0.1 & -0.4 & 0.7 & 1.1 & 0.9 & 0.7 & 0.9 & 0.8 \\
\hline
\end{tabular}

Source: Central Bank of Brazil.

$1 /$ Includes the federal government, the social security system and the central bank.

$2 /$ Includes total revenue and expenditure minus interest payments.

3/ Flows accumulated over 12 months to May 2004. 
Figure 1. Brazil's fiscal performance, 1990-2003

In per cent of GDP

A. Indebtedness and fiscal stance ${ }^{1}$

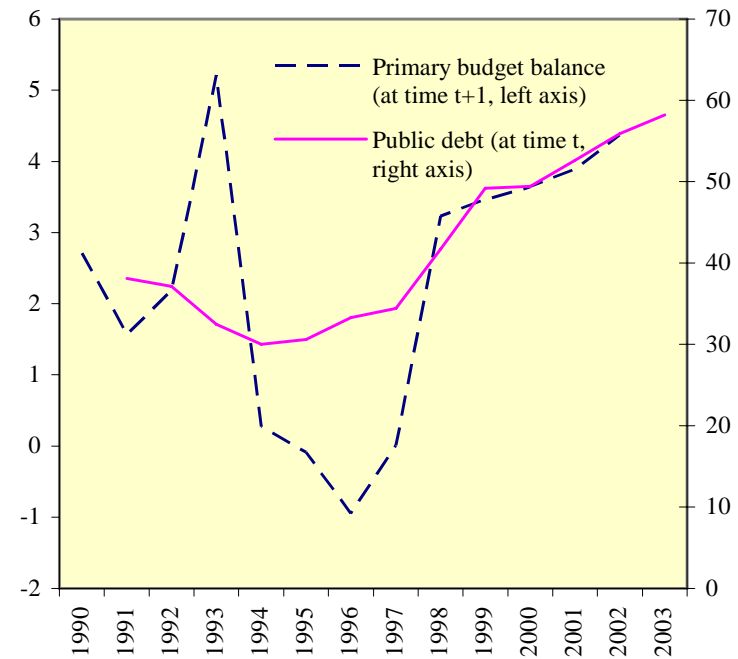

\section{Central government revenue and} expenditure

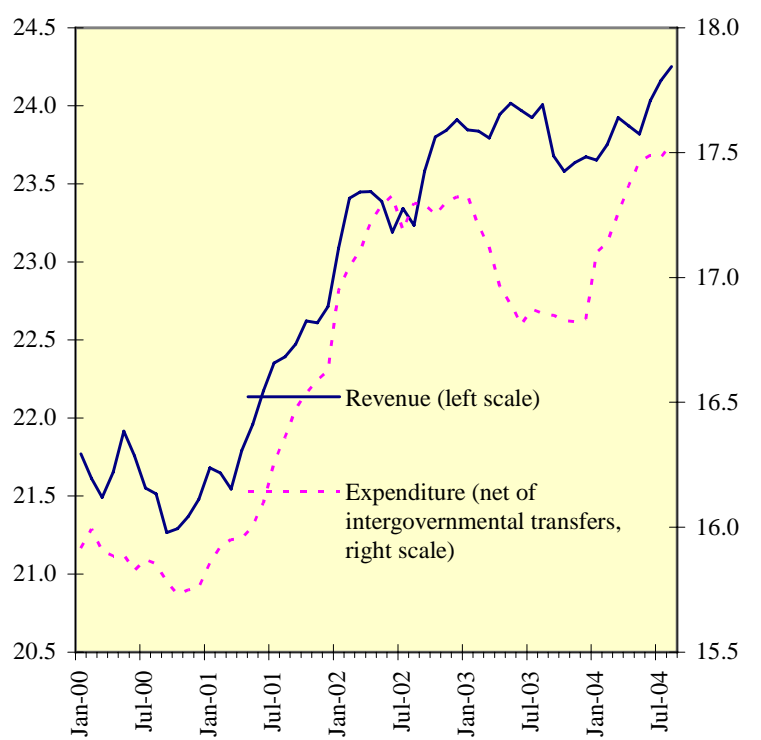

B. Fiscal stance over the business cycle ${ }^{2}$

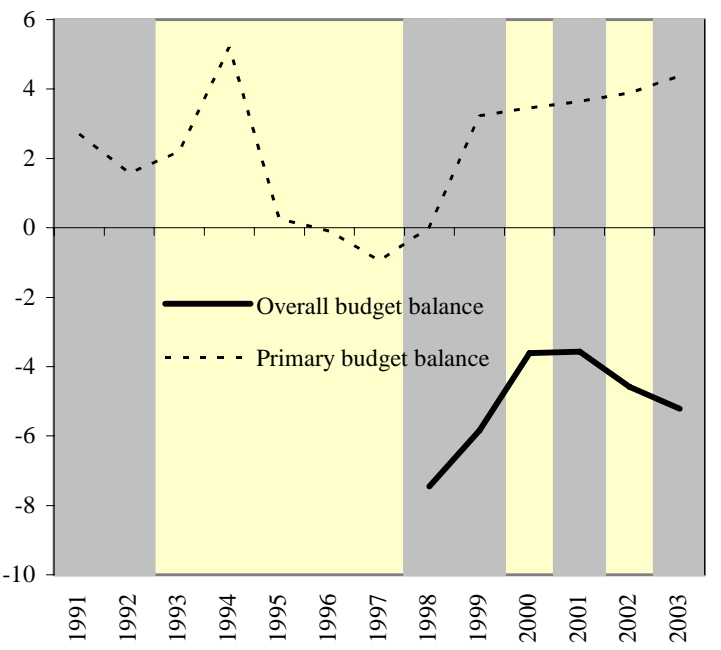

D. Central government outlays on pensions and discretionary programmes

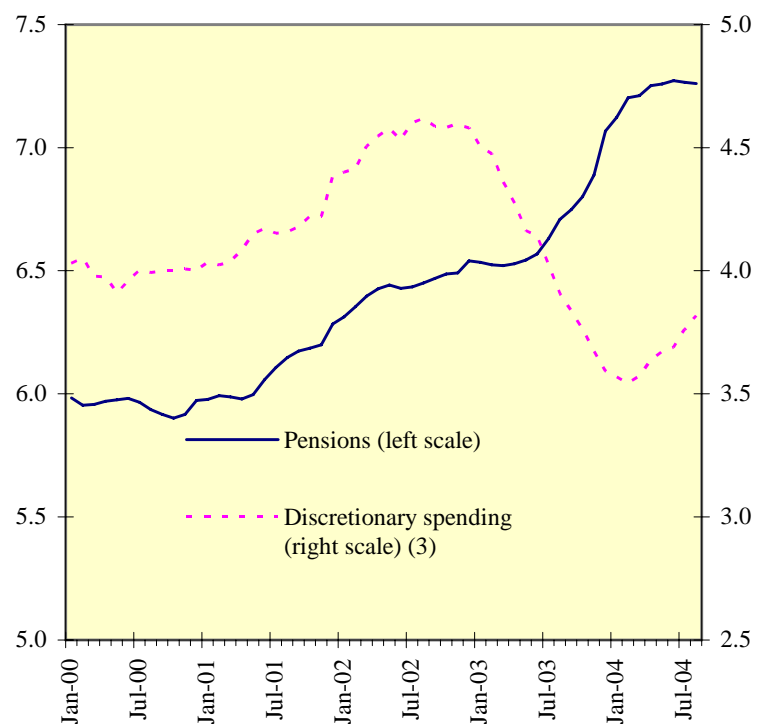

1. Refers to the consolidated public sector.

2. Refers to the consolidated public sector. The grey areas identify cyclical downturns, defined as the years in which changes in the ouput gap relative to the previous year are non-positive.The ouput gap is calculated as the percent difference between actual and HP-filtered GDP.

3. Measured as "other current and capital spending" (other OCCs).

Source: National Treasury, and author's calculations. 
- Fiscal consolidation has been achieved predominantly by hiking revenue. ${ }^{7}$ The ratio of tax revenue to GDP has risen to about 35 percent in 2004 from about 28 percent in 1995. The composition of revenue has also changed. At the federal level, while tax revenue has been broadly stable in relation to GDP, that of federal "contributions" (i.e., levies whose revenue is earmarked for specific programs, particularly in the social sectors, but not shared with the regional governments) has risen steadily. Contributions were originally levied on enterprise turnover and payroll, having a detrimental impact on Brazil's trade competitiveness and encouraging informality in the labor market. The main federal contributions have now been converted into value added-type taxes, somewhat mitigating this problem. The sub-national tax take has also increased over time, although, at the municipal level, greater effort towards fully exploiting local tax bases, which are often underutilized even in the OECD area, have been a welcome development.

- Downward rigidity in current spending has resulted in a compression of capital outlays in the course of fiscal adjustment. At the federal level, spending on investment came down from 0.6 percent of GDP in 1995 to 0.4 percent of GDP in 2003 and recovered somewhat in 2004. The state governments have compensated in part for this decline at the federal level. The existence of mandated minimum spending levels for several social programs contributed to budget inflexibility. ${ }^{8}$ At the same time, social security pressures have mounted and the creation of new expenditure commitments, particularly in old age-related assistance, has put additional upward pressure on current spending. Another source of budget inflexibility is revenue earmarking, which is widespread: it is estimated that about 80 percent of federal tax revenues are earmarked, against less than 60 percent in $1988 .{ }^{9}$

\section{The role of Fiscal Responsibility legislation}

\subsection{An overview of international practices}

6. Several countries have adopted "fiscal responsibility" legislation -- encompassing a variety of fiscal rules and administrative/managerial processes -- aiming at ensuring better discipline and efficiency at all levels of government. The scope of legislation varies a great deal across countries, as well as its

7. Empirical evidence for OECD countries suggests that fiscal adjustments are more successful when based on the retrenchment of current expenditure, rather than on hiking revenue and/or cutting back public investment. Governments that are able to cut the politically more sensitive components of the budget (public employment, social security and welfare programs, for example) may signal that they are more committed to sustained fiscal adjustment (McDermott and Wescott, 1996; Alesina and Perotti, 1997). Fiscal consolidation based on expenditure cuts, especially transfers and government wages, are more likely to succeed in reducing the debt ratio. Evidence for Latin America is limited, but, using Alesina and Perotti's (1997) methodology, Rocha and Picchetti (2003) show that Brazil's fiscal consolidation in 1994 was likely to be unsuccessful as it was achieved on the back of investment cuts, while wages and transfers remained unchanged.

8. The introduction in 1996 of a minimum spending level per student (primary and lower-secondary education) has been instrumental in increasing school enrolment rates and reducing pay disparities at the regional government level. The 2000 constitutional amendment setting a floor for aggregate federal spending on health care has also exacerbated downward rigidities.

9. An arrangement is currently in place for withholding federal earmarked revenues (Desvinculação das Receitas da União, DRU), mitigating in part the budget rigidity associated with revenue earmarking. Accordingly, 20 percent of federal revenue (net of intergovernmental transfers) are withheld by the federal government. Discussions are under way to implement a comparable arrangement at the state level. See Ministry of Planning and Budget (2003) and OECD (2005), for more information. 
coverage. The experience of OECD countries is illustrative of this diversity in institutional arrangements, although a few common elements can be highlighted: ${ }^{10}$

- Administrative controls are possibly the crudest form of fiscal rule. This is more prevalent in developing countries and emerging market economies. In some OECD countries, sub-national borrowing is subject to central government approval (Ireland, Japan, Korea and the United Kingdom), but rules are becoming more flexible in others (e.g., the Czech Republic, Hungary, Finland, New Zealand and Norway). In Mexico, the states and municipalities, including their decentralized agencies and public enterprises, are prohibited from borrowing abroad and can only borrow domestically to finance investment up to the ceilings set by their respective legislatures.

- More comprehensive fiscal rules include ceilings on public debt or debt service, expenditure or budget balances. These rules may be expressed in actual or cyclically-adjusted terms. In the OECD area, the overall budget balance is capped in Austria, Belgium, Finland, Sweden and Spain. In other countries, including France, New Zealand and Norway, the operational, rather than overall, budget balance is capped allowing borrowing for investment purposes. Golden rules (i.e., budgeted deficits must not exceed investment spending) are in place in Germany, Switzerland and the United Kingdom. ${ }^{11}$ Ceilings on the public debt and/or debt service outlays are also in place in some countries (Hungary, Poland and Portugal).

- Markets appear to be a poor substitute for fiscal rules, particularly at the sub-national level of government, but have complemented these rules in many cases, such as in Canada and the United States. Prudential regulations on investors' exposure to sub-national government debt are often weak, and information disclosure requirements tend to be more lenient on sub-national governments than on the central government and corporations.

- To embed some flexibility in fiscal rules, escape clauses are in place in many countries, allowing for deviations from fiscal targets under exceptional circumstances (e.g., Austria, Italy, Poland, some Canadian provinces and the European Union's Stability and Growth Pact).

7. International experience suggests that more is needed to enhance the effectiveness of fiscal rules by broadening their coverage and giving them a medium-term focus. In particular:

- It is sometimes easy to bypass fiscal rules through creative accounting. The expenditure ceilings in the United States' Budget Enforcement Act (BEA, in place up to 2002) could sometimes be circumvented by designating funds as emergency spending or by using advanced appropriations to spread budget authority over more than one year. Narrowing the coverage of legislation also creates problems. ${ }^{12}$ Other mechanisms for circumventing fiscal rules include the channeling of expenditure through the tax system, off-budgetary funds, public-private partnerships and loan guarantees.

10. See OECD (2002, Chapter IV; 2003a, Chapter V), for more information.

11. The United Kingdom introduced in 1997 a golden rule and a debt rule ("sustainable investment rule"), capping the ratio of net debt to GDP over the cycle at 40 percent. In Switzerland, an expenditure rule was introduced at the federal level in 2003 aiming at keeping the budget balance close to zero over the cycle and setting a ceiling for expenditure, which cannot exceed cyclically-adjusted revenue.

12. For example, the provision in the United States' BEA that legislated changes affecting revenue or mandatory spending programs (i.e., health care, unemployment benefits and farm price support) be budgetneutral did not apply to pensions. 
- The future costs of current policies can be underestimated when the policy framework is not transparent. This is the case if policy decisions granting tax expenditures, creating off-budgetary funds or committing public resources to public-private partnerships and loan guarantees are not subject to standard budgetary oversight and may be difficult to reverse. In this case, even if wellconceived, fiscal rules may fail to enhance fiscal probity.

\subsection{The case of Brazil $^{13}$}

8. Brazil's institutional framework for fiscal policymaking has evolved considerably over time. Two important precursors to the current institutional set-up -- enshrined in the Fiscal Responsibility Law of 2000 -- are: $i$ ) the sub-national debt restructuring programs sponsored by the National Treasury in 1997-98, and ii) the introduction of ceilings on personnel spending at the sub-national level (Box 1). In particular:

- The sub-national debt restructuring programs of 1997-98 were not a bail-out of the regional governments. They strengthened federal control over sub-national finances through the introduction of explicit, legally-binding sanctions for non-compliance and the use of shared revenue as collateral for the servicing of restructured debt. Continued enforcement of the debt restructuring contracts and restricted access to market financing have required a considerable fiscal adjustment by the states and municipalities to generate the primary surpluses needed to service their outstanding debt obligations. A comprehensive sub-national privatization program, particularly in the sectors of transportation and energy, was subsequently put in place in support of fiscal adjustment.

- The introduction of caps on personnel outlays was a first step towards the rules-based rationalization of sub-national spending. It was recognized that failure to retrench current expenditure would undermine any sustained effort towards fiscal consolidation, subsequently putting compliance with the debt restructuring arrangements at risk. The growth of sub-national personnel spending would also further reduce the ability of the regional governments to adequately provide public goods and services.

\section{Box 1. The evolution of fiscal institutions over time}

\section{Debt restructuring}

The debt restructuring arrangements between the National Treasury and the states (and the Federal District) date back to 1997. Similar arrangements were put in place in 1998 with over 180 municipalities (out of over 5,500 municipalities), including most of the larger ones. Prior to these arrangements, federal credit lines could be extended to indebted states under the condition that they implement comprehensive fiscal adjustment programs, consisting primarily of the gradual reduction of personnel spending in relation to current revenue, stricter control of public enterprises, including their privatization, and the introduction of primary surplus targets. These consolidation efforts did not always bear fruit, predominantly due to a lack of credible sanctions for non-compliance.

In the case of the 1997-98 arrangements, debt restructuring referred to outstanding liabilities incurred prior to November 30, 1995 (Credit Line I). Adjustment programs aimed at reducing personnel spending could also be financed within the framework for debt restructuring (Credit Line II), as well as the conversion of short-term revenue anticipation operations (AROs), a de facto modality of budget financing, into debt to be restructured (Credit Line III).

These arrangements -- formalized in bilateral contracts between the National Treasury and the sub-national jurisdictions -- are legally binding. They called for the down-payment of 20 percent of the jurisdiction's outstanding debt

13. This section draws from de Mello (2005), Appendix 2. 
liabilities, as well as a fixed repayment schedule based on below-market interest rates and revenue mobilization capacity, defined as the jurisdiction's total real net revenue, which includes own revenue and net constitutionallymandated transfers (i.e., mandated transfers from higher levels of government net of mandated transfers to lower levels of government). Non-compliance is sanctioned through the replacement of below-market interest rates by the nominal interest rate paid on the federal securitized debt plus a penalty of 1 percentage point per annum.

\section{Ceilings on personnel spending}

Ceilings on personnel spending were introduced in 1995 in support of sub-national fiscal retrenchment. Complementary Law No. 82 of 1995 (Camata Law I) set a ceiling for personnel spending of 60 percent of a jurisdiction's net current revenue, including pensions. Net current revenue is calculated by excluding from total current revenues constitutionally-mandated federal transfers, social security contributions of civil servants, and the jurisdiction's net position relative to Complementary Law No. 87 of 1997 (Kandir Law) and FUNDEF. ${ }^{1}$ Complementary Law No. 96 of 1999 (Camata Law II) maintained the same 60 percent ceiling but broadened the definition of personnel spending to include several modalities of fringe benefits that had been excluded from Camata Law I.

1. Complementary Law No. 87 of 1997 created a mechanism for compensating the states for the revenue losses associated with the exemption of VAT from exports of primary and semi-manufactured goods. FUNDEF is a fund created in 1998 to equalize spending capacity among the states and municipalities in the area of primary and lowersecondary education. The federal government sets a floor for outlays per student and tops up spending in the subnational jurisdictions that cannot afford the national spending floor. See de Mello (2001a and 2001b), for more information on FUNDEF, as well as Boxes 2 and 3.

9. The Fiscal Responsibility Law (FRL), enacted in May 2000, is emblematic of the strengthening of fiscal institutions in Brazil. The FRL sets a general framework for budgetary planning and execution applicable to all levels of government. Its main provisions are: ${ }^{14}$

- On revenue, the LRF mandates: $i$ ) the withholding of discretionary federal transfers to the states and municipalities that do not collect effectively their own taxes, and ii) the publication of the impact of tax exemptions on the budget, when the exemptions take effect and in two subsequent budgets.

- On expenditures, the LRF bans the creation of: $i$ ) permanent spending mandates without a corresponding increase in permanent revenue or a reduction in other permanent spending commitments; and ii) new spending commitments that cannot be executed before the end of the incumbent's term in office, as well as the recording of these as unspent commitments in the two quarters prior to the end of the incumbent's term in office, unless there are sufficient cash balances to cover them at the end of the fiscal year.

- The LRF contains a golden-rule provision for capital spending (i.e., annual credit disbursements cannot exceed capital spending).

- The LRF sets separate ceilings for personnel spending at each level of government (including pensions and payments to sub-contractors) equivalent to 50 percent of net current revenue for the central government and 60 percent of net current revenue for the states and municipalities, as well as sub-ceilings for the executive, legislative and judiciary branches of each level of government. If in breach of the personnel ceilings, the jurisdiction will not be allowed to engage in new credit operations, and sub-national governments will not be allowed to receive discretionary transfers or

14. See Nascimento and Debus (2001) and IMF (2001), for more information. 
credit guarantees from the federal government. The LRF also bans voluntary intergovernmental transfers to finance personnel spending without an explicit budget allocation in the budget laws of the jurisdiction providing the grants and benefits.

- The LRF contains stringent provisions on indebtedness and the issuance of public debt by the central bank. It also prohibits credit or debt restructuring operations among the various levels of government. Debt ceilings were set by the Senate in 1998 and 2001 at, respectively, 200 and 120 percent of net current revenue for the state and municipal governments. Although the ceilings on sub-national indebtedness are legally-binding, those for the federal government are yet to be set by law. When in breach of the debt ceilings, new financing and discretionary transfers to subnational governments are banned, including short-term revenue anticipation operations (ARO), other than those taken to refinance securitized debt.

- The LRF also contains escape clauses. The time frame for reducing personnel spending or indebtedness in excess of the mandated ceilings can be lengthened if the economy contracts by 1 percent or more during the previous 4 quarters, or a national catastrophe is declared by the legislature, as well as in the case of a state of siege. These escape clauses can only be exercised with congressional approval.

10. The LRF provides for more transparent fiscal reporting. ${ }^{15}$ Budget outturns are to be presented in bi-monthly budget execution reports, as well as more comprehensive four-month reports on compliance with the LRF, including the statement of corrective measures if the relevant provisions are breached. The municipalities are required to report to the Ministry of Finance the fiscal outturn of the previous year by end-April and the states by end-May. The Ministry of Finance is required to publish a consolidation of the public finances of the previous year by end-June. The legislative branch of each level of government, aided by their respective Courts of Accounts, monitors compliance with the fiscal targets and ceilings.

11. The LRF strengthens the legal framework for medium-term budgeting. ${ }^{16}$ The LRF requires the inclusion of a Fiscal Policy Annex to the Multi-Year Budget Framework Law (PPA) of the federal government with multi-year fiscal targets and the inclusion of a Fiscal Targets Annex to the Budget Guidelines Law (LDO) for all levels of government. The LDO is also required to include an annex describing fiscal risks with an assessment of contingent liabilities. By introducing more stringent requirements on fiscal targets in the preparation of the LDO, the LRF strengthens its role in budget preparation and fiscal management in general. In particular:

- The Fiscal Targets Annex requires the assessment of compliance with the fiscal targets of the previous years and the analysis of the net worth of the public enterprises, with emphasis on the use of resources from privatizations and asset sales in general. This is to avoid the use of capital revenues to finance current spending and the inclusion of these revenues above the line to generate higher primary balances.

15. The municipalities with less than 50000 inhabitants face less stringent provisions on budget reporting.

16. There are three integrated budget framework horizons in Brazil. First, a 4-year budget framework (PPA) is defined by the federal government to allocate its projected budgetary resources over the following years to different programs and activities, consistent with the medium-term macroeconomic framework, fiscal targets and revenue forecasts. Second, a 3-year Budget Guidelines Law (LDO) sets targets for the main budget aggregates (expenditure, revenue, budget balance and debt) for the current year and indicative targets for the following two years. Third, an annual budget law (LOA) allocates budget resources to the programs and activities defined in the PPA and consistent with the targets set in the LDO. Programs and activities, as well as their costs, are clearly identified in the preparation of the PPA and in the LOA. 
- The Fiscal Risks Annex requires a detailed assessment of the government's contingent liabilities, including an evaluation of the likelihood of adverse outcomes in legal disputes. In the case of the central government, the Fiscal Risks Annex provides a detailed assessment of the impact on revenues of changes in the macroeconomic framework, as well as deviations from the macroeconomic parameters based on which the annual budget law (LOA) is formulated.

- The LRF strengthens the link between the LDO and the LOA. This is achieved by requiring the LOA to abide by the LDO's fiscal targets (detailed in the LDO's Fiscal Targets Annex), the inclusion of a contingency reserve defined in percent of net current revenues to be used for the settlement on unspent commitments (restos a pagar) of the previous year, as well as contingent liabilities that may materialize in the reference period, the reporting of tax expenditures and the inclusion in the LOA of debt service obligations in the reference period.

12. Complementary to the FRL is the Fiscal Crimes Law (FCL). The FCL applies to public officials of the executive, legislative and judiciary branches of the federal, state and municipal governments, as well as their decentralized agencies and public enterprises. Among other provisions, the FCL provides for detention of up to four years for public officials who: i) engage in credit operations without prior legislative authorization (or in breach of the credit or indebtedness ceilings), ii) incur expenditure commitments in the last two quarters of his/her term in office that cannot be paid within the current fiscal year or without adequate cash balances, iii) incur unauthorized expenditure commitments, iv) extend loan guarantees without equal or higher-value collateral, v) increase personnel expenditures in the 180 days prior to the end of his/her term in office, and vi) issue unauthorized unregistered public debt.

13. Prudential regulations limiting the exposure of financial institutions to government debt, including that of sub-national levels of government, have been complementary to the FRL. Financial institutions' exposure to the government (all levels of government, public enterprises and decentralized agencies combined) is limited to 45 percent of their net worth, including all credit operations and loan guarantees. These institutions also face stringent provisioning requirements, at 150 percent of the value of loans to the public sector. More recently, it has been recognized that these constraints have restricted access to finance by some regional jurisdictions that were compliant with the debt and debt service ceilings set under the FRL. Prudential regulations were therefore introduced in 2003 setting aggregate caps on credit operations with the municipalities to finance investment in water and sanitation, subject to the observance by each individual borrower of the debt service ceilings set under the FRL. These aggregate caps are consistent with the government's target for aggregate spending on these programs. The option of introducing similar aggregate caps for investment in transport infrastructure is under discussion, pending an assessment of the measures introduced for water and sanitation against the expected increase in government spending on these programs.

\section{Municipal finances and infrastructure investment}

\subsection{Local government spending and economic performance: a word of caution}

14. Although a case can be made for increasing local government investment in search of stronger economic performance, often through the reassignment of these expenditure functions across the different levels of government, a few considerations are noteworthy. In particular, an increase in local government spending, particularly on infrastructure, need not enhance economic performance for the economy as a whole. Empirical evidence on the link between fiscal decentralization and economic growth is mixed. For example, Davoodi and Zou (1998) show that local government spending is growth-reducing in developing 
countries, but no causal link is found in the case of developed countries. ${ }^{17}$ Likewise, Zhang and Zou (1998) report a negative correlation between post-reform decentralization and economic growth in a sample of Chinese provinces. On the other hand, in a somewhat different strand of literature, Glaeser et al. (1995) report a positive impact of local investment in sanitation on population growth in a panel of 260 cities in the United States. In the case of Brazil, de Mello (2002) provides evidence based on for a panel of 26 state capitals in the period 1985-94 suggesting that municipal spending on health care, sanitation, housing and urbanization are important growth determinants at the municipal level. General infrastructure investment and municipal spending on transport services are also reported to be strongly correlated with growth.

15. The scope for enhancing economic performance by boosting local government spending on infrastructure depends on how these outlays are financed. Overlapping responsibilities across the different levels of government, reliance on open-ended grants for financing service delivery and weak accountability can create an upward bias in sub-national spending, with adverse macroeconomic consequences. Conversely, central governments may transfer spending functions without taking full account of their costs, and these unfunded mandates may force the sub-national authorities to cut back investment or raise taxes to keep their own accounts in balance. The empirical evidence reported by de Mello (2002) for Brazilian state capitals suggests that municipal borrowing is detrimental to growth. This is not surprising, since borrowing increases indebtedness and debt servicing tends to displace resources that could otherwise be used to finance growth-enhancing expenditures.

16. It is believed, as elsewhere in Latin America, that Brazil suffers from an "infrastructure gap", which is an obstacle to faster growth, and that financial resources are needed to close the gap. ${ }^{18}$ While there is considerable demand for infrastructure building and upgrading in developing countries, it should also be noted that not all public investment is productive and that a reduction in public capital spending need not necessarily be disruptive. This is particularly the case where local government spending is financed in a fiscally unsustainable manner. Evidence reported by Devarajan et al. (1996) for a panel of 43 developing countries suggests that the investment component of public expenditure may turn out to be unproductive when financed by instruments that misallocate government spending at the expense of current expenditures.

17. The association between fiscal decentralization and performance indicators in the infrastructure sector is not clear-cut. It is difficult to find unequivocal empirical evidence in this area. For example, the cross-country evidence reported by Estache and Sinha (1995) suggests that more decentralized countries tend to spend more on infrastructure projects, particularly in the developing world. This is possibly due to the fact that differences in local preferences are better taken into account in more decentralized countries. But, at least as gauged by the cross-country empirical evidence reported by Humplick and Estache (1995), the performance of several infrastructure projects, including roads, electricity and water, does not seem to improve significantly as a result of greater sub-national spending on infrastructure.

18. Another consideration is with respect to the claim that fiscal rules tend to reduce the ability of local governments to invest. This may not necessarily be the case. Evidence for developing countries is not readily available but the experience of the United States, where the states have had a variety of balanced budget rules for a relatively long period, suggests that rules may indeed induce some pro-cyclicality in the sub-national fiscal stance, which may nevertheless be mitigated through the accumulation of rainy day funds in good times. These funds can be used not only for the purpose of short-term demand management,

17. Davoodi and Zou (1998) analyze the relationship between fiscal decentralization and economic growth from a cross-country perspective using a sample of 46 countries over the period 1970-89. Emphasis is placed on sub-national governments as a whole, and not only on local government spending.

18 . See Tanzi (2005), for more discussion on the "infrastructure gap" in Latin America. See also Prud'homme (2004) for more information. 
which nevertheless tends to be of a limited scope at the sub-national level, but also, and more importantly, to avoid disruption in the financing of public investment in bad times. ${ }^{19}$ In this regard, evidence provided by Sorensen et al. (2001) suggests that the states that have relatively tight balanced-budget rules seem to have less pronounced swings in both revenue and expenditure over the business cycle than the states with less stringent fiscal rules.

\subsection{Overview of Brazilian municipal finances: a focus on infrastructure investment ${ }^{20}$}

19. There are several constraints to the ability of Brazilian local governments to boost spending on infrastructure investment. They range from institutional provisions on the assignment of expenditure functions across and within the different levels of government to a lack of budget flexibility, against a backdrop of increasing downward rigidities in current spending and on-going fiscal adjustment.

20. On institutional constraints, the Brazilian Constitution empowers the local governments to delegate to the private sector, often through concessions, the provision of local services such as urban transportation, and water and sanitation. These services, together with housing and urbanization, are provided primarily by the municipalities (Table 2). Other services requiring considerable infrastructure investment, such as inter-municipal transport and gas distribution, are under the purview of the states, whereas energy, telecommunications and inter-state transportation, among others, are assigned to the federal government. ${ }^{21}$

19. This is consistent with the evidence reported by Bohn and Inman (1996), which, although sensitive to the cyclical indicator used to gauge fiscal responsiveness, indicates that stringent fiscal rules encourage precautionary savings in good times, which can be used subsequently to finance counter-cyclical measures in bad times. By contrast, also using U.S. state data, Alesina and Bayoumi (1996) argue that fiscal rules have indeed reduced flexibility in state-level fiscal policymaking without, however, having a bearing on the cyclicality of state fiscal policy.

20. The source of data on municipal finances is the National Treasury. The data refer to the balance sheets of the municipalities, excluding their decentralised agencies (autarquias and fundações) and off-budget funds (including pension funds). The number of municipalities in the sample, which spans the period 1998-2003 varies between 3807 in 1998 and 4881 in 2001. Due to methodological constraints, intertemporal comparability is ensured within the periods 1998-2001 and 2002-03. The National Statistics Bureau (IBGE) also publishes municipal data based on the national accounts but the coverage is less comprehensive and data are typically available with a two-year lag.

21. This assignment of expenditure functions across the different layers of government is consistent with the principle of subsidiarity, whereby services should be delivered by the lowest level of government capable of internalizing the externalities associated with public provision. In principle, the assignment of expenditure functions to sub-national governments is constrained by the ability of smaller jurisdictions to make the most of economies of scale in service delivery. The other important constraints are spillover effects, by which the inhabitants of adjacent jurisdictions can benefit from spending in another, which may result in the underprovision of services or stretch local budgets beyond their means. 
Table 2. Composition of public social spending, 2002

In per cent of GDP

\begin{tabular}{|c|c|c|c|c|}
\hline & \multirow[t]{2}{*}{ Total } & \multicolumn{3}{|c|}{ Levels of government } \\
\hline & & $\begin{array}{c}\text { Central } \\
\text { government }\end{array}$ & States & Municipalities \\
\hline Total public social spending & 24.4 & 13.3 & 5.8 & 5.2 \\
\hline Social asistance & 0.9 & 0.5 & 0.1 & 0.2 \\
\hline Social security & 10.7 & 9.2 & 1.2 & 0.3 \\
\hline Health care & 4.7 & 1.9 & 1.3 & 1.5 \\
\hline Sanitation & 0.4 & 0.0 & 0.2 & 0.2 \\
\hline Labour & 0.7 & 0.6 & 0.0 & 0.0 \\
\hline Education & 5.4 & 1.0 & 2.6 & 1.8 \\
\hline Culture & 0.2 & 0.0 & 0.1 & 0.1 \\
\hline Civil rights & 0.2 & 0.0 & 0.1 & 0.0 \\
\hline Housing & 0.1 & 0.0 & 0.1 & 0.1 \\
\hline Urbanisation & 1.0 & 0.0 & 0.1 & 0.9 \\
\hline Land reform & 0.1 & 0.1 & 0.0 & 0.0 \\
\hline
\end{tabular}

Source: Ministry of Finance.

21. The municipalities are becoming more active in the provision of social services. This is essentially the case of health care, with the decentralization of the national health system (SUS) in the early 1990s, and education, particularly after the implementation of FUNDEF in 1997-98 (Box 2). These two functions accounts for almost one-half of municipal spending, but outlays are financed predominantly through revenue sharing and earmarked revenue. In some cases, municipal governments are also involved in the provision of conditional income transfers to poor households, a social expenditure more often financed by the central government.

\section{Box 2. FUNDEF}

FUNDEF is a fund (created in 1996 and implemented in 1997-98) to finance sub-national spending on primary and lower-secondary education. While primary spending is assigned to the municipalities by the Constitution, the states were the main providers of services until the late 1990s. FUNDEF changed the mechanism for financing subnational spending on education in two main ways. First, a national spending floor was introduced per student enrolled in primary and lower-secondary education $\left(1^{\text {st }}\right.$ to $8^{\text {th }}$ grades), coupled with a framework for the allocation of funds between the state and municipal public school networks. Second, FUNDEF requires the federal government to top up spending in those states that cannot afford the national spending floor. Since 2000, different floors have been set for primary education ( $1^{\text {st }}$ to $4^{\text {th }}$ grades) and for lower-secondary education ( $5^{\text {th }}$ to $8^{\text {th }}$ grades), at 5 percent above the value for primary education. ${ }^{1}$

FUNDEF is financed by earmarking 15 percent of i) the state and municipal allocations in the revenue-sharing funds with the federal government, ii) revenue from the state value-added tax (ICMS), iii) revenue from the federal value-added tax levied on exports (IPlexp), and iv) federal transfers to the states associated with ICMS revenue insurance (i.e., a mechanism for compensating the states for the revenue losses associated with the exemption of value added tax on the exports of primary and semi-manufactured goods). FUNDEF resources are allocated within each state according to the number of students enrolled in the state and municipal public school networks. At least 60 percent of FUNDEF allocations must be spent on personnel, with the remaining share being spent on operations and maintenance. Within FUNDEF, the municipalities are required to spend at least 25 percent of their revenue on education (at least 15 percent on primary education). 
FUNDEF is associated with a rapid increase in enrolment rates in primary and lower-secondary education. Although this increase cannot be attributed solely to FUNDEF, there appears to be a strong association between changes in enrolment rates and in the composition of enrolment between the state and municipal school networks, which has been changing over time in favor of the municipal school network. Based on evidence for a data set including 26 state capitals in the period 1991, 1994, and 1998-2001, enrolment rates were estimated to have risen rose by more than 2 percent per year faster after the introduction of FUNDEF than in the period 1991-98. ${ }^{2}$

1. See de Mello (2001a, 2001b), Afonso and de Mello (2002), and Ministry of Education (2003), for more information.

2. See de Mello and Hoppe (2005) and OECD (2005), for empirical evidence.

22. The municipalities face downward rigidities in their budgets, constraining their ability to reallocate funds to finance outlays on investment. The existence of minimum spending levels for education and health care impose downward rigidity in current spending, as in the case of the federal government, although revenue earmarking is less pervasive than at the federal level. The municipalities (as well as the states) are required by the Constitution to earmark 25 percent of revenue (18 percent for the federal government) to finance spending on education and 15 percent of revenue (12 percent for the states) to finance the provision of health care. At the same time, spending on personnel, including pensions to retired civil servants, places a heavy burden on municipal budgets (Figure 2). Outlays on debt service, consistent with continued compliance with the debt restructuring arrangements with the National Treasury, reduces the room for manoeuvre in indebted jurisdictions.

23. The ability of the municipalities to finance infrastructure investment is also constrained by their revenue raising capacity, which tends to be lower than at the state and federal levels. The municipalities tax services (except for communications and inter-state/inter-municipal public transportation), property and, to a lesser extent, raise revenue through user fees and charges (Box 3). Revenue sharing is another important source of revenue at the municipal level, particularly for the smaller municipalities, which have low revenue mobilization capacity (Table 3). ${ }^{22}$ However, the formula for allocating shared revenue among the municipalities in a given state favors smaller municipalities to the detriment of larger jurisdictions and metropolitan areas, where the demand for public provision may be strongest. ${ }^{23}$

22. The distribution of population is unequal across Brazil's 5560 municipalities. In the sample of municipalities used in this paper, three-quarters of the municipalities had population less than 22405 in 2000. See IBAM (2001) and Souza (2004), for more information.

23. According to Rezende and Garson (2004), the 10 main metropolitan areas, accounting for 30 percent of the population and 50 percent of GDP, received only 12.7 percent of FPM funds in 2002. 
Figure 2. Trends in municipal expenditure, 1998-2003

In per cent of municipal current expenditure, weighted averages ${ }^{1}$

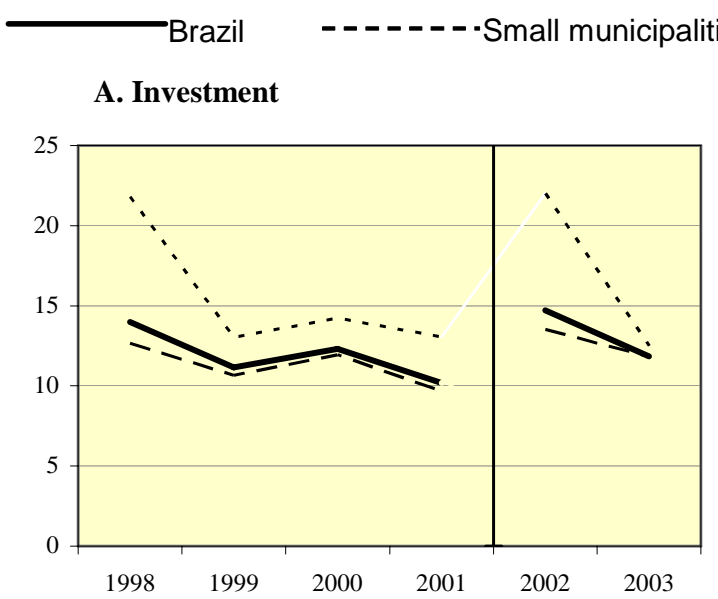

\section{B. Personnel}

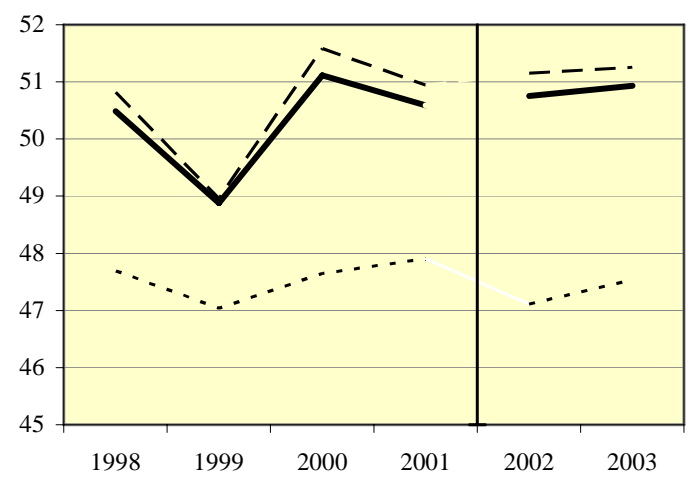

C. Transport

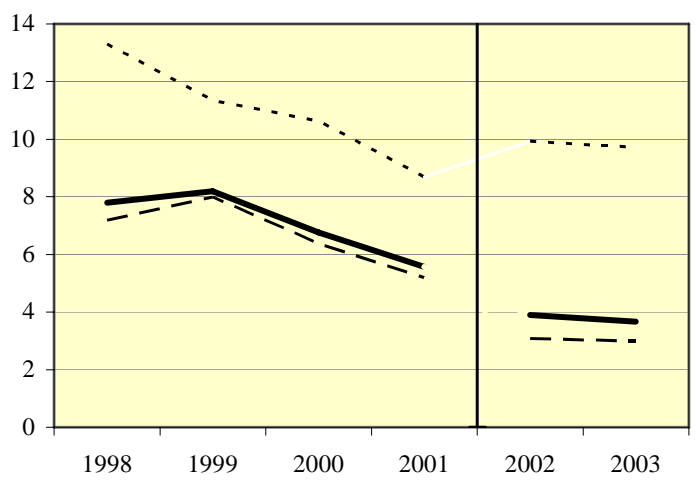

D. Debt service: interest and amortization

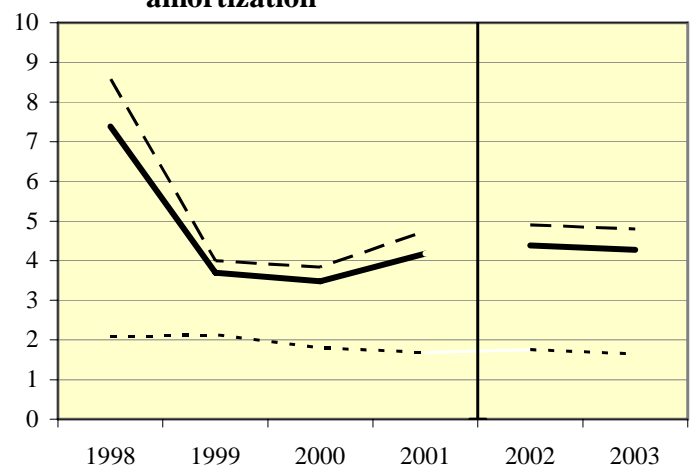

\section{E. Health care and sanitation}

F. Housing and urbanisation
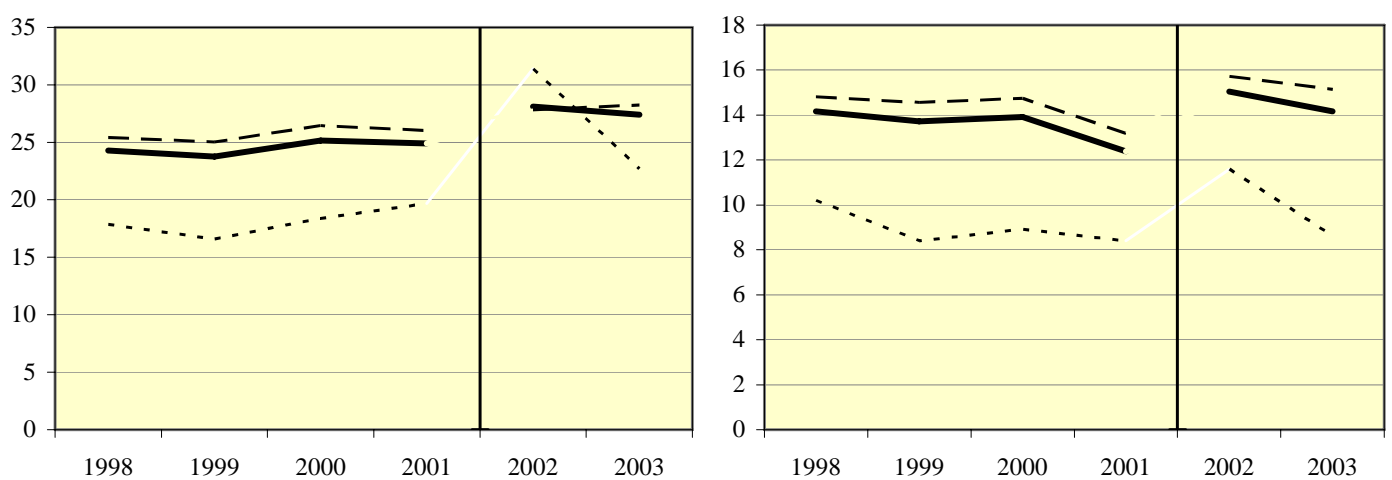

Source: National Treasury, and author's calculations.

1. The number of municipalities varies between 3807 in 1998 and 4881 in 2001.

2. Refers to the municipalities with population less than 5102 inhabitants in 2000 , which are in the lowest quartile of the distribution.

3. Refers to the municipalities with population higher than 22425 in 2000 , which are in the highest quartile of the distribution. 
Table 3. Composition of municipal revenue, 2002

In per cent of GDP

\begin{tabular}{|c|c|c|c|}
\hline & $\begin{array}{c}\text { All } \\
\text { municipalities }\end{array}$ & $\begin{array}{l}\text { Metropolitan } \\
\text { areas }\end{array}$ & $\begin{array}{c}\text { Non- } \\
\text { metropolitan } \\
\text { areas }\end{array}$ \\
\hline Total revenue & 7.9 & 4.0 & 4.0 \\
\hline Own sources & 1.5 & 1.2 & 0.4 \\
\hline Local property tax (IPTU) & 0.5 & 0.4 & 0.1 \\
\hline Services tax (ISS) & 0.6 & 0.5 & 0.1 \\
\hline Transfer tax (ITBI) & 0.1 & 0.1 & 0.0 \\
\hline Other taxes & 0.1 & 0.1 & $\ldots$ \\
\hline User charges and fees & 0.2 & 0.1 & 0.1 \\
\hline Shared revenue & 3.2 & 1.3 & 1.9 \\
\hline Municipal Participation Fund (FPM) & 1.2 & 0.2 & 1.0 \\
\hline ICMS & 1.5 & 0.7 & 0.8 \\
\hline Motor vehicle registration tax & 0.2 & 0.1 & 0.1 \\
\hline Federal income tax (IRRF) & 0.2 & 0.1 & 0.0 \\
\hline Other & 0.1 & 0.0 & 0.1 \\
\hline Specific grants and compensatory transfers & 2.2 & 0.9 & 1.2 \\
\hline Health care & 0.5 & 0.2 & 0.2 \\
\hline FUNDEF & 0.7 & 0.2 & 0.5 \\
\hline Other current transfers & 0.7 & 0.4 & 0.3 \\
\hline Capital grants & 0.3 & 0.1 & 0.2 \\
\hline Other Revenues & 1.0 & 0.6 & 0.4 \\
\hline
\end{tabular}

Source: Rezende and Garson (2004).

\section{Box 3. Municipal revenue}

\section{Municipal taxes}

The main municipal taxes are those on services (ISS) and urban property (IPTU). In particular:

- $\quad$ ISS rates are set by the municipalities subject to the ceilings introduced by the federal government. Rates can vary considerably across sectors. Tax legislation is designed to avoid overlap with federal corporate income and state value-added taxes. In the banking sector, for example, ISS is levied on non-lending services such credit card and ATM fees but not on the interest charged on loans, which is taxed by the federal government. In the case of land transportation, ISS is levied on intra-municipal transport but not on intercity or interstate transport, which are subject to the state value added tax.

- $\quad$ IPTU is levied on the capital value of land and buildings in legally-designated urban areas. Property valuations are based on the physical characteristics of each property converted to an estimate of market value using construction cost parameters and surveys of land prices. These valuations are adjusted each year on the basis of an inflation index.

\section{Revenue sharing}

Based on constitutionally-mandated revenue sharing (Box Table 1), the municipalities are entitled to: i) 25 percent of revenue from the state value-added tax (ICMS), ii) 50 percent of revenue from the state tax on motor vehicle registration (IPVA), iii) 22.5 percent of revenue from the federal value added (IPI) and income (IR) taxes, iv) all revenue from the income tax held at source (IRPF) and paid by the municipalities or by their decentralized agencies, $v$ ) 70 percent of revenue from the federal financial transactions tax levied on transactions with gold (IOF-Ouro), and vi) 50 
percent of revenue from the federal rural property tax (ITR).

Constitutional Amendment No. 42 of 2003 increased the municipal revenue sharing rate by 1 percentage point, to 23.5 percent of IPI and IR, leaving the rate unchanged for the states; introduced the sharing of revenue from the federal excise on petroleum derivatives (CIDE-Combustíveis) with the municipalities (25 percent of the state share in revenue); and increased the revenue sharing rate for ITR to 100 percent if the municipality opts for collecting this tax.

Box Table 1. Intergovernmental transfers to municipal

governments, 2002

In per cent of GDP

\begin{tabular}{lc}
\hline & All municipalities \\
\cline { 2 - 2 } & \\
\cline { 2 - 2 } Total & 4.9 \\
Contitutional transfers & 3.9 \\
$\quad$ Revenue sharing & 3.0 \\
$\quad$ of which: & \\
FPM (Municipal Participation Fund) & 1.2 \\
ICMS (Value Added Tax) & 1.5 \\
IPVA (Tax on Motor Vehicle) & 0.3 \\
Compensatory transfers & 0.8 \\
of which: & \\
ICMS revenue insurance & 0.1 \\
FUNDEF (Fund for Education) & 0.7 \\
Non-constitutional transfers & 0.9 \\
of which: & \\
Health care & 0.5 \\
Capital & 0.3 \\
Other & 0.2 \\
\hline Source: Afonso and Araujo (2004).
\end{tabular}

\section{Compensatory transfers}

Compensatory transfers include: i) the Fund for the Compensation of Exports (FPEx), consisting of 10 percent of total collection of IPI, proportional to the value of exports of industrialized goods, ${ }^{1}$ ii) royalties for the exploitation of petroleum and natural gas, hydroelectricity and other mineral resources in their territory or in the adjacent maritime platform, iii) ICMS revenue insurance, consisting of compensation for the exemption of ICMS from the export of primary and semi-manufactured goods; ${ }^{2}$ and iv) FUNDEF allocations.

\section{Other transfers}

The main additional transfers refer to health care and voluntary transfers associated primarily with investment programs.

1. It is distributed to the States and, in turn, to the municipalities. The states have to share 25 percent of this transfer with the municipalities.

2. The municipalities are entitled to 25 percent of the ICMS revenue insurance.

24. Municipal borrowing is low in comparison with higher levels of government, reflecting their lower debt repayment capacity, on-going fiscal adjustment and limited access to markets. Municipal fiscal stance, as gauged by the primary budget balance (excluding municipal enterprises), has fluctuated over time (Figure 3). The municipalities of São Paulo, Rio de Janeiro and Salvador account for about 75 percent of outstanding municipal debt. The debt restructuring arrangements discussed above, the introduction of 
debt ceilings in the context of Fiscal Responsibility legislation, and the issuance by the Central Bank over the years of prudential regulations on the exposure of banks to the private sector have been instrumental in curtailing the rise in municipal indebtedness, despite the deterioration since early 2003.

Figure 3. Municipal indebtedness and primary budget balance, 1998-2004 12-month flows, in per cent of GDP

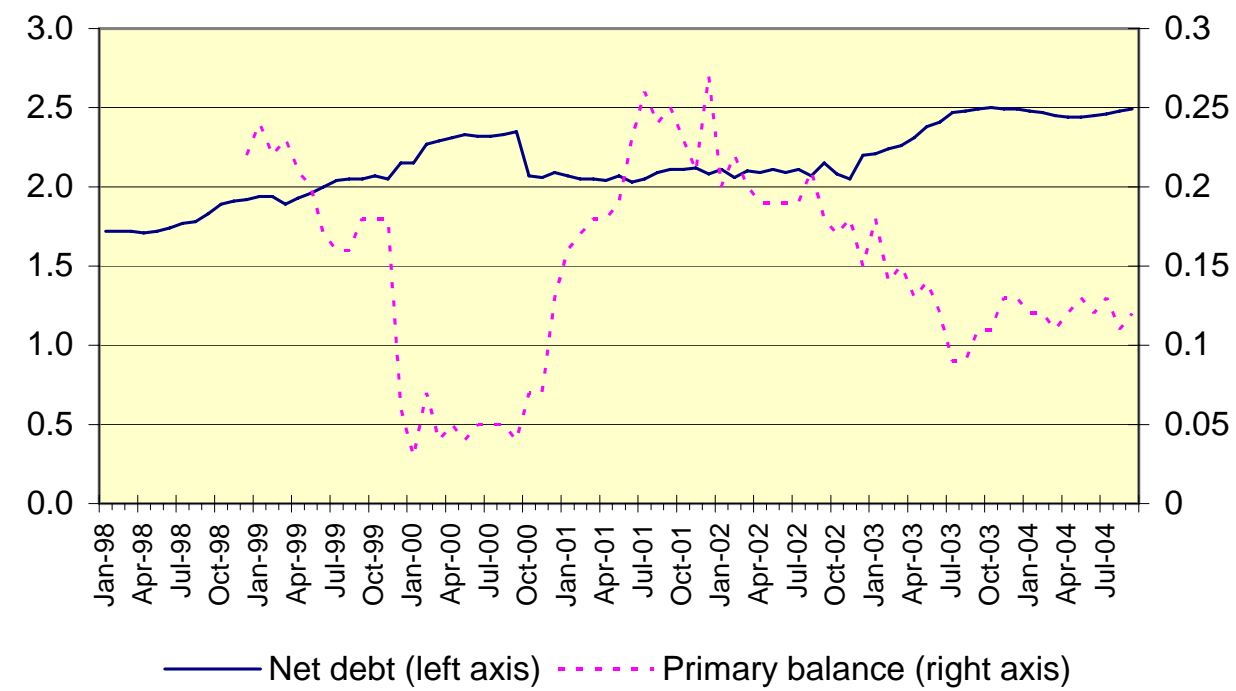

Source: Central Bank of Brazil.

25. In addition to these constraints on the ability of local governments to finance the provision and upgrading of infrastructure, regulatory uncertainty in some sectors has discouraged private investment.

- The private sector has traditionally been involved in service delivery in the case of urban transportation, predominantly through concessions. Regulatory uncertainty and constraints on pricing that simultaneously meets the requirements of private investors and the purchasing power of the population has deterred greater private sector involvement in other areas.

- In the case of water/sanitation, public investment has been cut back over the years without an offsetting increase in private investment. This can be attributed predominantly to a lack of clarity about which level of government is responsible for service delivery and regulation in the sector. ${ }^{24}$ Investment, both public and private, has also been discouraged by the externalities associated with the provision of sewerage and water treatment services, and because water/sanitation networks are costly, investment maturities are long, and rates of return are relatively low. This is particularly the case in the metropolitan regions, which straddle municipal borders. These trends are important

24. According to the 1988 Constitution, the municipalities are in charge of granting concessions for "local" public services, while the federal and state governments should guarantee efficient and well-regulated water supply and sanitation services. The 1995 Concession Law provided more guidelines for private concessions but did not clarify which level of government is in charge of water and sanitation provision. The Concession law challenged the monopolies that state companies enjoyed for 25 years, stating that the municipalities also have the right to grant concessions or enter into licensing agreements for "local" services or provide these services themselves. Prior to 1994, a decline in the inflation-adjusted value of user charges contributed to lower investment capacity. See Parlatore (2000), for more information. 
because, despite progress in increasing access by the population to drinking water, connection rates to sanitation, and in particular to wastewater treatment, remains low. ${ }^{25}$

\section{Conclusion}

26. Important constraints on the provision of infrastructure investment by local governments are the sunk costs involved in funding these programs, as well as spillovers and economies of scale effects. The sunk costs may be prohibitive in view of local governments' limited revenue mobilization capacity, including access to finance. But there are options for overcoming these difficulties. For example, crossborder joint ventures have been encouraged in many countries to maximize economies of scale and to internalize the externalities associated with the provision of regional public goods. The OECD experience is illustrative. In France, for instance, small communes contract out service delivery to private regional water companies, and contiguous municipalities often create regional associations to manage services such as waste disposal. Municipalities in Norway frequently co-operate in such sectors as waste disposal, water supply and energy (through the joint ownership of power plants). In Latin America, Peru attempted to decentralize much of its road network to provincial and municipal governments but then failed to provide financing for operations and maintenance (Gutman, 1999). This resulted in widespread deterioration of the network and, ultimately, recentralization (Burki, Perry, and Dillinger, 1999; Humplick and Moini-Araghi, 1996). In Brazil, there are inter-municipal water/sanitation companies, particularly in the case of large metropolitan areas, where the networks straddle local government borders.

27. Another option for mobilizing the private sector in the provision of infrastructure investment is through public-private partnerships (PPPs). At the core of PPP operations is the need to achieve an appropriate balance of risk between the government and its private-sector partners. In Brazil, new legislation has been approved creating instruments for providing private-sector partners with guarantees that the financial commitments entered into by the government in these projects will be honored. The government will be able to create fiduciary funds in a financial institution to honor these commitments. These funds can be capitalized with resources from the budget, non-tax credits, non-financial assets and real estate, among others. Revenues from PPP projects accruing to the government can also be earmarked to finance the settlement of contractual obligations. Several state governments have also passed PPP legislation (i.e., Goiás, Minas Gerais, Rio Grande do Sul, Santa Catarina and São Paulo). Options for the provision of financial guarantees vary across the states: Minas Gerais, Santa Catarina and Rio Grande do Sul have opted for the creation of fiduciary funds along the lines of federal legislation, whereas São Paulo and Goiás have created public companies linked to the state treasuries to manage state guarantees.

28. While there are options for boosting local government spending on infrastructure, when deemed cost-effective and growth-enhancing, it is important to safeguard fiscal responsibility. To this end, the Brazilian legislation on PPPs calls for the accounting and reporting of commitments entered into by the governments in PPP contracts in line with the provisions of Fiscal Responsibility legislation for all levels of government. Of particular importance in this regard is vigilance over the possibility of misclassification of debt-creating commitments as current spending as a means of bypassing the debt ceilings set by law. The introduction of a ceiling on government outlays related to PPP projects, possibly defined as a share of

25. While about 80 percent of households have access to piped water, less than two-thirds are connected to public sewerage networks or septic tanks. Moreover, there are large regional disparities in connection rates between the northern and south-eastern states, large and small municipalities, and rich and poor households. In 2000, connection rates for urban households to public sewerage and non-rudimentary septic tanks was 56 and 16 percent, respectively, while for rural households they were 3 and 10 percent, respectively (IBGE, 2000). Urban sewerage coverage reached 70 percent in the South-East but only 2 percent in the North. Only 9 percent in poor rural areas had access to piped water in 2000, although some had access to wells and springs. Of all households earning less than two minimum wages, two-thirds had access to piped water and one-third to sewerage. See OECD (2005), for more information. 
net current revenue, such as the debt service ceilings already provided for by the Fiscal Responsibility legislation, is therefore welcome. Consistency between long- and short-term budgetary objectives should also be preserved, given the long-term duration of PPP contracts. However, the assessment of risks and transparency is complicated by heterogeneity in reporting as required by the different audit courts within and across different levels of government. Therefore, the Treasury has an important role to play in standardizing accounting and reporting requirements. State legislation also requires PPP contracts to be in line with budget legislation, requiring the assessment of the budgetary impact of projects prior to contracting. It is expected that limits will be set through prudential regulations on the exposure of public financial institutions to PPP projects. 


\section{REFERENCES}

Afonso, J.R., and L. de Mello (2002), “Brazil: An Evolving Federation”, in Managing Fiscal Decentralization, edited by E. Ahmad and V. Tanzi, London, Routledge.

Afonso, J.R., and E.A. Araújo (2004), “Local government organisation and finance”, World Bank, Unpublished manuscript.

Alesina, A. and S. Ardagna (1998), “Tales of Fiscal Contractions”, Economic Policy, Vol. 27.

Alesina, A. and T. Bayoumi (1996), "The Costs and Benefits of Fiscal Rules: Evidence from US States”, NBER Working Paper, No. 5614.

Alesina, A. and R. Perotti (1997). "Fiscal adjustments in OECD countries: Composition and Macroeconomic effects”, IMF Staff Papers, Vol. 44, No. 2, pp. 210-248.

Bohn, H. and R.P. Inman (1996), "Balanced-Budget Rules and Public Deficits: Evidence from the U.S. States”, Carnegie-Rochester Conference Series on Public Policy, Vol. 45.

Davoodi, H., and Zou, H.-F. “Fiscal Decentralization and Economic Growth: A Cross-Country Study”, Journal of Urban Economics, 43(1998), 244-57.

Devarajan, S., V. Swaroop, and H.-F., Zou (1996), "The Composition of Public Expenditure and Economic Growth”, Journal of Monetary Economics, Vol. 37, pp. 313-44.

de Mello, L.R. (2001a), “Social Spending in Brazil: Education and Health Care”, Brazil: Selected Issues and Statistical Appendix, International Monetary Fund, Washington, DC.

de Mello, L.R. (2001b), “Social Spending in Brazil: Recent Trends in Social Assistance”, Brazil: Selected Issues and Statistical Appendix, International Monetary Fund, Washington, DC.

de Mello, L.R. (2002), "Public Finance, Government Spending and Economic Growth: The Case of Local Governments in Brazil,” Applied Economics, Vol. 34, pp. 1871-83.

de Mello, L.R. (2005), "Estimating a Fiscal Reaction Function: The Case of Debt Sustainability in Brazil”, OECD Economics Department Working Paper No. 423, OECD, Paris.

de Mello, L.R. (2006), “Estimating a Fiscal Reaction Function: The Case of Debt Sustainability in Brazil”, Applied Economics, forthcoming.

Estache, A. and S. Sinha (1995), "Does Decentralization Increase Spending on Public Infrastructure?,” World Bank, Washington, D.C.

Giavazzi, F., T. Jappelli, and M. Pagano (2000), “Searching for non-linear effects of fiscal policy: evidence from industrial and developing countries”, European Economic Review, Vol. 44. 
Glaeser, E.L., J.A. Scheinkman, and A. Shleifer (1995), “Growth in a Cross-Section of Cities”, Journal of Monetary Economics, Vol. 36, pp. 117-43.

IBAM (2001). Evolução do quadro municipal brasileiro no período entre 1980 e 2001, Série Estudos Especiais No. 20, IBAM, Rio de Janeiro.

IMF (2001), Brazil: Report on Observance of Standards and Codes (ROSC), Fiscal Transparency Module, Country Report No. 01/217, IMF, Washington, D.C.

IMF (2003), World Economic Outlook, IMF, Washington, DC.

McDermott, J. and R.F. Wescott (1996), “An Empirical Analysis of Fiscal Adjustments”, IMF Staff Papers, Vol. 43, No. 4, pp. 725-53.

Martner R. and V. Tromben (2004), "La Sostenibilidad de la Deuda Pública, el Efecto Bola de Nieve y el "Pecado Original””, Serie Gestión Pública, No. 46, ILPES/ECLAC, Santiago.

Ministry of Education (2003), Relatório Sobre a Fixação do Valor Mínimo Nacional por Aluno/ano, Ministry of Education, Brasília.

Ministry of Planning and Budget (2003), Vinculações de Receitas dos Orçamentos Fiscal e da Seguridade Social e o Poder Discrecionário de Alocação dos Recursos do Governo Federal, Federal Budget Secretariat, Brasília.

Nascimento, E.R. and I. Debus (2001), Entendendo a Lei de Responsabilidade Fiscal, Unpublished manuscript.

OECD (2002), Economic Outlook, No. 72, OECD, Paris.

OECD (2003a), Economic Outlook, No. 74, OECD, Paris.

OECD (2005), OECD Economic Survey of Brazil, OECD, Paris.

Parlatore, A.C. (2000), "Privatização no Setor de Saneamento no Brasil”, in A.C Pinheiro and K. Fukasaku (eds.). A Privatização no Brasil: o Caso dos Serviços de Utilidade Pública, OECD/BNDES, Rio de Janeiro.

Prud'homme, R. (2004), “Infrastructure and Development”, Paper prepared for the Annual Bank Conference on Development Economics, World Bank.

Reinhart, C., K. Rogoff, and M. Savastano (2003), “Debt Intolerance,” Brookings Papers on Economic Activity, Brookings Institution, pp. 1-62.

Rezende, F. And S. Garson (2004), "Financing metropolitan areas in Brazil: political, institutional, legal obstacles and emergence of new proposals for improving coordination”, Unpublished manuscript.

Rocha, F. and P. Picchetti (2003) Fiscal adjustment in Brazil, Revista Brasileira de Economia, Vol. 57, No. 1, pp. 239-52.

Sorensen, B.E., L. Wu and O. Yosha (2001), “Output fluctuations and fiscal Policy: US State and local governments 1978-94”, European Economic Review, Vol. 45. 
Souza, C. (2004), “Governos locais e gestão de políticas sociais universais”, Unpublished manuscript.

Tanzi, V. (2005), “Building Regional Infrastructure in Latin America”, Inter-American Development Bank, Unpublished manuscript.

Zhang, T. and H.-F. Zou (1998) "Fiscal Decentralization, Public Spending, and Economic Growth in China”, Journal of Public Economics, Vol. 67, pp. 221-40. 